\title{
INFLUENCE OF ENVIRONMENTAL CONDITIONS AND APPLICATION OF CLEANING METHODS AGAINST BIODETERIORATION OF MARBLE MONUMENTS
}

\author{
P. Spathis a*, A. Pantazidou b, M. Mavromati a, E. Papastergiadis a \\ a * Dept. of Chemistry, Aristotle University of Thessaloniki, Thessaloniki 54006 Greece, \\ spathis@chem.auth.gr \\ b Dept. of Biology, University of Athens, Athens, Greece
}

KEY WORDS: marble, environmental conditions, biodeterioration, cleaning.

\begin{abstract}
The aim of this paper is the study of the effect of environmental factors on the deterioration of marble monuments and the selection of a suitable and effective cleaning method. One of the main deterioration problems of the monuments is biodeterioration. It was obvious the presence of thick layers of biological patina, covering all almost surfaces of these. The growth of microorganisms, bacteria and plants is enhanced from the particular environmental conditions, that combine increased moisture, insolation and temperature, an area full of plants and trees and can cause extensive chemical and mechanical decay of the monuments. The growth of microorganisms, bacteria, plants and lichens was observed and determined. The influence of specific weathering agents and factors to the behavior of the materials was examined. The chemical composition of bulk precipitation and also the physicochemical characteristics of the surface and underground water were investigated. The environmental conditions and the growth of physical microorgamisms on the surface of the materials led to loss of the structural cohesion and the surface instability of the building materials. A series of various mechanical and chemical cleaning methods were tested in the laboratory containing the use of distilled water, microsandblast, organic solvents, absorbing clays, $\mathrm{NH}_{4} \mathrm{HCO}_{3}$ solution, biocides (desogen, hydrogen peroxide). In situ tests were carried out with satisfactory results in the monuments when a method of combination of hydrogen peroxide solutions, EDTA, $\mathrm{NH}_{4} \mathrm{HCO}_{3}$ solution and organic solvent was applied in various steps on the monument surface.
\end{abstract}

\section{INTRODUCTION}

Deterioration of historical monuments is the result of chemical reactions of polluted air, soil and water with the stone building materials. The crystallization and hydration of weathering products result in their expansion causing the degradation of dolomite, limestone, marble, sandstone and other building materials. In most cases the stone surfaces are gradually covered by salts and black crusts containing calcium, magnesium, sodium, potassium sulphates, nitrates and other constituents. Also water can easily penetrate and remain into the building stone materials, resulting in a destructive influence due to the absorption and evaporation of the moisture that affects their volume and causes cracks leading to the deterioration of the structure (Young 2008). Under these conditions, the stone surfaces disintegrate into powder and the building materials gradually lose their mechanical strength and their artistic form (Price, 1996; Winkler, 1997; Lan et al., 2005; Skoulikidis, 2000; Moreno et al., 2006). In the case of marbles the main mechanism of deterioration is the sulphation of their surfaces, leading to the formation of gypsum layers on the stone surface, due to the solid state diffusion of $\mathrm{Ca}^{2+}$ (Camuffo et al., 1982; 1983; Del Monte et al., 1984; Rodriguez-Navarro et al., 1996; Keatings, 2007; Simao et al., 2006; Sharma et al., 2007). The deterioration of rocks that are exposed to the atmosphere is a continuing, composite and complex procedure due to physical, chemical and biological processes. The presence and activity of microorganisms in organic or inorganic materials have resulted in the recommendation biodeterioration. The degree and type of damage are related to the climate of the region of development of the microorganisms (nature of mineral, organic material, etc.). Organisms such as algae, bacteria, fungi and animal organisms when deployed in urban areas or in the countryside, on the surface and inside the building material of monuments contribute, depending on the type of organism, with chemical and/or mechanical processes in the biodeterioration of the material.

Biodeterioration of marble includes physical and chemical processes. The accumulation of micro-organisms in the surface of the stone and existing small wells, exacerbates the damage with physical or chemical procedures. Mechanical fracture and dislocation of the structure of minerals is caused due to pressure, which comes from the development of organisms or their parts (roots). This is important when the organisms or micro-organisms do not restrict the size of the surface, but penetrate drastically in the material. Also indirect mechanical actions are induced, especially during frost phenomenon: absorption of humidity, expansion and contraction of the gelatinous canisters that characterize most land forms e.g. algae, resulting in changes of environmental conditions and alteration of substrate. Organisms and microorganisms secrete from their roots acids (strong or weak) which react immediately with the rock corroding mineral, forming complexes salts or destroying it.

Lichens and bryophytes are resistant organisms, suffering long periods of moisture without being destroyed. They absorb, store and desorb rapidly humidity, depending on the environmental conditions. They do not have a root system, but they have strong mechanisms for snapping in the substrate. These properties make them the most dynamic colonists of the building materials of the monuments. A porous surface is more favourable to colonization. The effect of lichens and bryophytes on the monument depends on the specie, the nature and chemical composition of the substrate. Many lichen or bryophyte species retain humidity in the snapping area, causing physical and chemical alterations of the substrate. Many lichens secrete oxalic acid, produce 
organic acids (by-products of metabolism) and carbon dioxide, leading to chemical corrosion and deterioration of the material (Ahmadian et al., 1983; Ascaso et al., 1994; Sawidis et al., 1995; Scagel et al., 1965).

The historic cemetery of Drapano on Kefalonia island, Greece, was founded during the $6^{\text {th }}$ decade of the $19^{\text {th }}$ century and contains monuments of a great historic, artistic and aesthetical importance. The monuments, plates, reliefs, columns, crosses, busts, reliquaries, statues, with historic inscriptions on theirs surfaces, were made from marble and stone and most of them were built during the last decades of $19^{\text {th }}$ century. The marble used for the construction of the monuments was from Naxos island and the stone from a topical region of Kefalonia; Markatou (1994), Kounadi (1985), Tzouganatos (1996). The cemetery is situated in an area near the sea, full of plants and trees, combining increased moisture, insolation and temperature and presence of organic compounds. These particular environmental conditions enhance the growth of microorganisms, bacteria and plants that can cause extensive chemical and mechanical decay of the monuments. It is obvious the presence of thick layers of biological patina, covering great parts and even all almost surfaces of these. So, one of the main deterioration problems of the monuments is biodeterioration.

\section{EXPERIMENTAL}

A series of samples were collected from three different marble monuments. The chemical analysis of the bulk and the surface of the samples was carried out by the Energy Dispersive Spectrometer (EDS-LINK AN 10/55S) of the Scanning Electron Microscopy (SEM) and the mineralogical analysis by X-R Diffraction ( Philips diffractometer, $\mathrm{CuKa}$ radiation, Ni filter, $2 \Theta=3^{\circ}-53^{\circ}$, with $\mathrm{ASTM}$ cards of the International Centre for Diffraction Data). Samples with various microorganisms were collected from different sites and marble monuments. The locations of sampling were selected based on macroscopic observations about the kind of organism, the type of decay of the material, the distance from the ground, the orientation of the surface and the moisture of the material. The samples, after suitable treatments, were examined macroscopically and microscopically. Twelve samples of bulk precipitation were collected on a monthly basis using a bulk precipitation collector located in the archaeological area for a period of one year. Twelve samples of sea and surface waters were also collected from the neighboring lagoon and a rillet, passing near the archaeological area. Upon receipt in the Laboratory, precipitation and water samples were filtered through 0.45 $\mu \mathrm{m}$ pore diameter cellulose membranes to remove particles. Chemical analysis for the determination of the chloride, nitrate and sulphate ions was carried out by Ion Chromatography.

\section{Cleaning}

The laboratory cleaning tests were carried out in 3 marble samples.

Mechanical cleaning. All samples were washed with distilled water for the removal of unstable deterioration products. The surface of the samples was cleaned by shooting of thin powder of small bullets (diameter $50-150 \mu \mathrm{m}$ ) of $\mathrm{Al}_{2} \mathrm{O}_{3}$. The controlled conditions of operation (microsandblast) lead to the removal of the superficial patina.

Chemical cleaning. Organic solvents were used for the removal of fatty compounds.
-Absorbing clays: They have a great specific area and a high ability of absorption of aqueous solutions and they can be used for the cleaning of biological patina and soluble salts. A paste of absorbing clays (sepiolithos) with water was produced that it was applied in the samples for 3 days. The procedure was repeated 4 times.

$-\mathrm{NH}_{4} \mathrm{HCO}_{3}$ solution. A solution of $7 \%$ of $\mathrm{NH}_{4} \mathrm{HCO}_{3}$ in water with the addition of non-acidic paper, in order to produce a paper-pulp, was used for the removal of the soluble salts. It was applied for 24 hours and the procedure was repeated 3 times.

-Desogen 3-5\%. Desogen is a biocide compound and also during the cleaning process decreases the superficial tension between patina and solution, making easier its removal. It was applied for 24 hours and the procedure was repeated 2 times.

-Solution of hydrogen peroxide $\left(\mathrm{H}_{2} \mathrm{O}_{2}\right) 10-15 \%$. It was used for the removal of the biological patina, due to its strong oxidising properties. It dissolves the colouring substances and the organic compounds.

The last step of the chemical cleaning was the wash of the surface with distilled water and the measurement of $\mathrm{pH}$ of the water that is removed from the surface, to confirm that it is the same with the one of the distilled water.

Ultraviolet radiation. Ultraviolet radiation $(250 \mathrm{~nm}$ wave length, $40 \mathrm{~W}$ lamp, distance from the sample $10-20 \mathrm{~cm}$ ) was used for the removal of the biological patina. It was applied for a period of one week.

\section{RESULTS AND DISCUSSION}

From the results of the chemical and mineralogical analysis follows that the material used for the construction of the marbles monuments was the same and is mainly composed of calcite (96-99\%), the remaining been quartz (1-2\%) and clays (1-3\%). The results were similar for both bulk and surface samples of marble. Deterioration problems due to air pollution or acid attack were not observed.

The historic monuments are sited very near the sea. The subsoil of the area consists mainly from permeable calcite rocks. To examine the possible influence of these conditions to the deterioration of the monuments, the physicochemical characteristics of the seawater are presented in Table 1. The results of the chemical analysis of bulk precipitation and surface water for major anions are shown in Table 2 and 3 the climate parameters and conditions are presented in Table 3.

Table 1 Physicochemical characteristics of seawater (annual variation)

\begin{tabular}{|c|c|c|c|}
\hline $\begin{array}{c}\text { Cl- ions } \\
(\mathrm{g} / \mathrm{L})\end{array}$ & $\begin{array}{c}\text { Nitrate ions } \\
(\mathrm{mg} / \mathrm{L})\end{array}$ & $\begin{array}{c}\text { Sulphate ions } \\
(\mathrm{g} / \mathrm{L})\end{array}$ & \multicolumn{1}{|c}{} \\
\hline $16.3-21.5$ & $0.2-0.9$ & $1.6-2.7$ & \\
\hline $\begin{array}{c}\text { Suspended } \\
\text { solids }(\mathrm{mg} / \mathrm{L})\end{array}$ & $\begin{array}{c}\text { Conductivity } \\
(\mathrm{mS} / \mathrm{cm})\end{array}$ & $\begin{array}{c}\text { Temperature } \\
\left(\mathrm{t}^{\circ} \mathrm{C}\right)\end{array}$ & $\mathrm{pH}$ \\
\hline $18-31$ & $22-54$ & $13-26$ & $7.5-8.5$ \\
\hline
\end{tabular}

Table 2 Concentrations of sulphates, nitrates and chlorides in surface waters and rainwaters (annual variation)

\begin{tabular}{|c|c|c|}
\hline \multicolumn{3}{|c|}{ Surface water } \\
\hline Chloride $(\mathrm{mg} / \mathrm{L})$ & Nitrate $(\mathrm{mg} / \mathrm{L})$ & Sulphate $(\mathrm{mg} / \mathrm{L})$ \\
\hline $300-600$ & $4.7-11.8$ & $25-40$ \\
\hline \multicolumn{3}{|c|}{ Rain water } \\
\hline Chloride $(\mathrm{mg} / \mathrm{L})$ & Nitrate $(\mathrm{mg} / \mathrm{L})$ & Sulphate $(\mathrm{mg} / \mathrm{L})$ \\
\hline $140-180$ & $2.5-4.4$ & $10-20$ \\
\hline
\end{tabular}



CLEANING METHODS AGAINST BIODETERIORATION OF MARBLE MONUMENTS

Table 3 Climate parameters

\begin{tabular}{|c|c|c|}
\hline \multicolumn{3}{|c|}{ Temperature $\left(\mathrm{t}^{\circ} \mathrm{C}\right)$ (annual variation) } \\
\hline $\min$ & $\max$ & average \\
\hline $0-14$ & $20-40$ & $11-26$ \\
\hline $\begin{array}{c}\text { Relative Humidity } \\
\text { (annual variation) }\end{array}$ & \multicolumn{2}{|c|}{ rainfall } \\
\hline $64-73$ & $\begin{array}{c}\text { total(per month- } \\
\text { annual variation) }\end{array}$ & Max (per 24h) \\
\cline { 2 - 3 } & $6-150$ & $26-190$ \\
\hline
\end{tabular}

From the results of the chemical analysis of the rain and surface waters follows that chlorides exhibited elevated concentrations, suggesting transport of marine aerosol in rain water and salt water intrusion from the sea in surface water. It is also evident that there are not significant amounts of nitrates or sulphates (except the case of nitrate in surface water, due possibly to the surrounding agricultural land). This observation is in accordance with the mentioned results of the mineralogical analysis, where no presence of crystallized salts on the surface or inside the pores of the materials it is observed. Significant variations of the temperature and the rainfall values during the year are observed correlated with dry/wet, cool/warm periods of time.

From the macroscopic observation it is obvious the presence of thick layers of biological patina, covering great parts or all almost surfaces of these. The colour of the patina varies from white, yellow, green or black. Also in some cases layers of unstable corrosion products and black crust are observed. These observations confirm that the main deterioration problem of the materials is biodeterioration, due to the growth of microorganisms, bacteria and plants, enhanced from the particular environmental conditions.

From the microscopic examination of the selected samples of microorganisms follows that the kinds found on the surfaces of the marble or in contact with it are algae (mainly cyanophyta), lichens, bryophytes, vacteria and mikytes. The determined cyanophyta are forms which often found in limestone rock located in conditions of adequate lighting, temperature and humidity and possibly moved and settled in the marble from the surroundings. Cyanophyta and lichens form on the surface of the material visible macroscopic green, orange, yellowish, brown or black overlays and coatings. The identification was based on the study of morphological traits in natural and cultivated material, (Komarek \& Anagnostidis, 1986), (Anagnostidis \& Komarek, 1988). The qualitative and quantitative microflora composition reveals that the study area of the cemetery with the sculptures is characterized by "eutrophic" and "oligotrophic" areas. "Eutrophic" are the positions that are characterized by a build-up of soil with slow drainage and good development of bryophytes. Such areas were found at the base of statues (terraces), on plates, trenches and wells of the structural material. These positions, since they are rich in organic and inorganic nutrients and moisture, present conditions favourable to establish and develop even higher plants in the future. The greatest variety of cyanophyta species observed is attributed to this phenomenon. In contrast, smooth, flat, dry and uniform chromatic surfaces of material are "ligotrophic" areas of the ecosystem of the monument and show little diversity and settlement of cyanophyta.

The kinds of algae (mainly cyanophyta), lichens, bryophytes, vacteria and mikytes found on the surfaces of the marble or in contact with it and the corresponding photo images are shown in Figure 1 and Table 4.

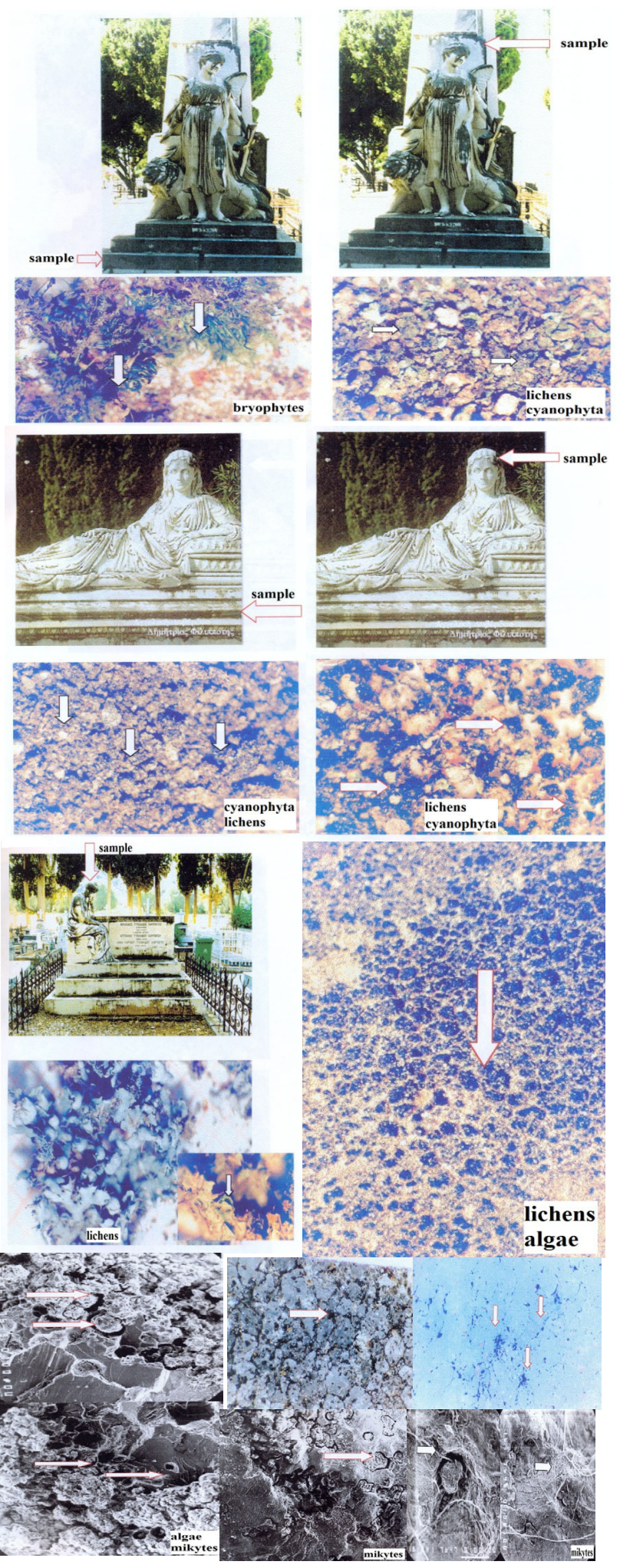

Figure 1 Sampling sites, stereoscope and scannind electron microscopy images of ajgae, cyanophyta, lichens,

bryophytes, vacteria and mikytes found on the surfaces of the marble 
Table 4 Identification of cyanophyta found in monuments area.

\begin{tabular}{|l|l|}
\hline Aphanocapsa sp. & Leptolyngbya cf. boryanum \\
\hline Aphanocapsa grevillei & Leptolyngbya foveolarum \\
\hline Calothrix cf. parietina & Leptolyngbya tenue \\
\hline Chroococcidiopsis sp. & Myxosarcina chroococcoides \\
\hline Chroococcus minor & Myxosarcina sp. \\
\hline Chroococcus minutus & Nostoc sp. \\
\hline Cyanosarcina cocinna & Nostoc spaericum \\
\hline Cyanosarcina sp. & Oscillatoria tenuis \\
\hline Chroococcus minutus & Phormidium corium \\
\hline Chroococcus minutus & Pseudanabaena catenata \\
\hline Gloeocapsa sanguinea & Schizothrix sp. \\
\hline Gloeocapsa sp. & Tolypothrix byssoidea \\
\hline $\begin{array}{l}\text { Leptolyngbya } \\
\text { angustissima }\end{array}$ & \\
\hline
\end{tabular}

The results of the laboratory application of the various cleaning methods on a marble sample are described below. Biological patina covered all surface of the sample, as it is observed in Figure 2a, where the initial situation of the sample it is shown. For the cleaning it was applied, in part of the sample to be obvious the results of the cleaning, distilled water and organic solvents, biocide, hydrogen peroxide, $\mathrm{NH}_{4} \mathrm{HCO}_{3}$, sepiolithos and microsandblast. The application of hydrogen peroxide removed a first layer of biological patina and after that microsandblast was applied for the total removal of the patina. A kind of yellow patina is observed on the sample, due to the action of some microorganisms that have the ability to remove the ferrous ions from the bulk of the material and concentrate these in the surface where they are oxidised forming yellow ferrous oxides that they are a kind of physical patina and must not be removed. The images of the sample during the cleaning procedure are shown in Figures 2b-2d, (intermediate steps) and Figure 2e, (final situation).

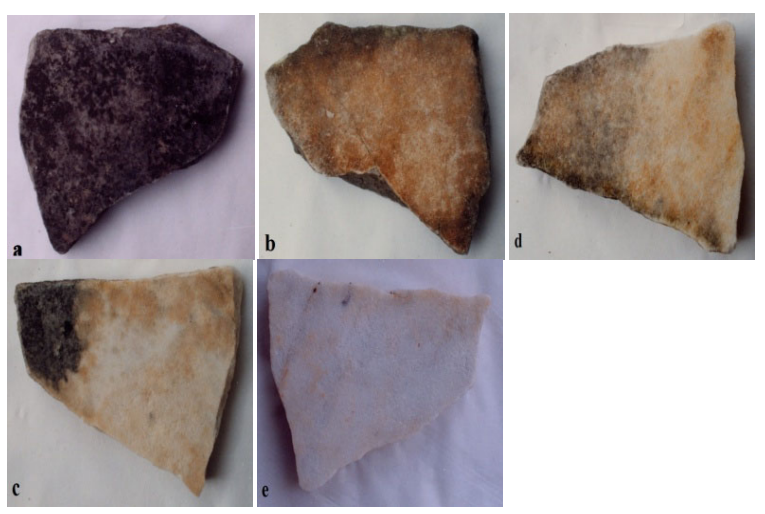

Figure 2 Procedure of cleaning of $\mathrm{M}_{1}$ marble sample; a: initial situation, b-d: intermediate steps, e: final situation

\section{In situ application of cleaning methods on marble monuments}

The monuments where the cleaning methods tested in laboratory experiments were applied are shown in Figures 3a, $4 \mathrm{a}$ and also Figures $3 \mathrm{~b}, 4 \mathrm{~b}$, where parts of the statues with representative problems of deterioration are shown. From these figures it is obvious the presence of thick layers of biological patina of a green, blue or orange colour, covering great parts of various areas of the statues. In some cases, layers of insoluble salts of brown colour or black crust and also deteriorated parts of the surface with cracks on it are observed. From these observations it is evident that biodeterioration caused serious problems not only on the surface of the statues but also and inside the pores of the marble.

Cleaning Procedure:

Typaldou statue

The initial situation of the statue is shown in Figures 3a,b. After a mind mechanical cleaning with water, a solution of Hydrogen peroxide $10 \%$ was used for the removal of the biological patina but with mediocre results. A paste of hydrogen peroxide $25 \%$ with paper-pulp was applied for 3-4 hours in areas of thick layers of biological patina with satisfactory results (Fig. 3c). A paste of EDTA 12\% was applied for 1 hour for the removal of the layers of insoluble salts and lead to a partial removal of the salts (Fig. 3d). After that the repeated application of a solution of hydrogen peroxide $25 \%$ for 5 hours had very satisfactory results (Fig. 3e).

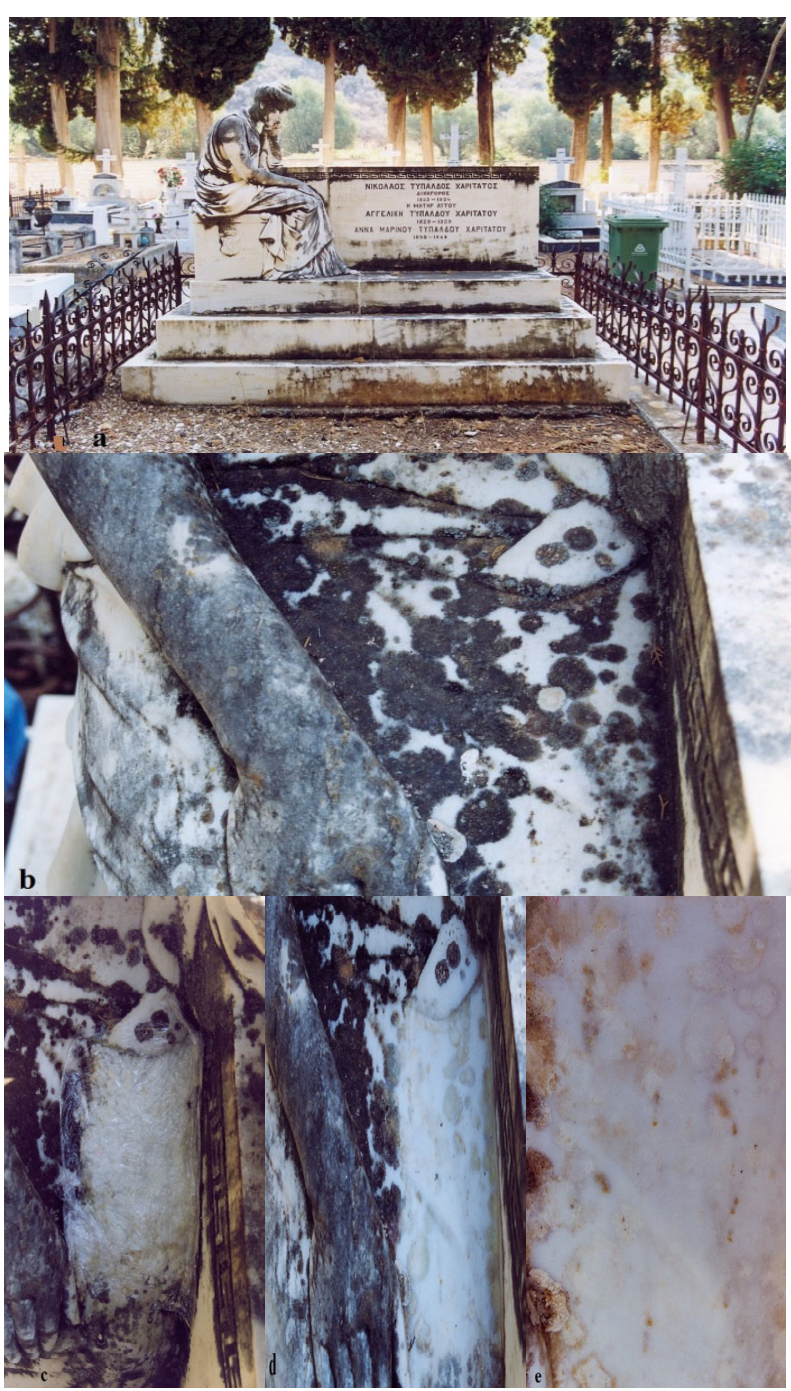

Figure 3 In situ application of cleaning methods on a marble monument (Typaldou statue); a: general view-initial situation, b: detail-initial situation, c-d: intermediate steps, e: final situation. 


\section{CLEANING METHODS AGAINST BIODETERIORATION OF MARBLE MONUMENTS}

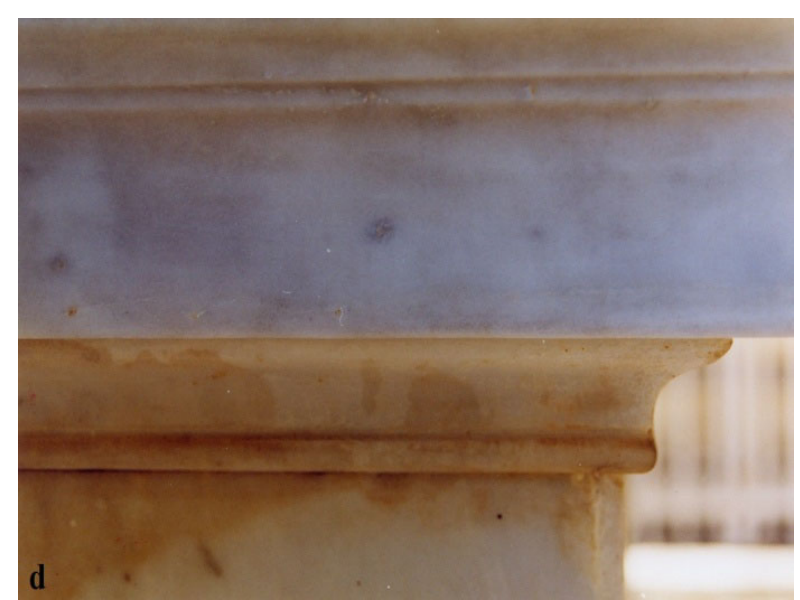

\section{Kosmetatos statue}

The initial situation of the statue is shown in Figures $4 a, b$ (biological patina - black crusts). Mechanical cleaning, spaying with a solution of Hydrogen peroxide $10 \%$, application of a paste of hydrogen peroxide $25 \%$ with paperpulp for 5 hours and application of a paste of EDTA $12 \%$ for $2 \mathrm{~h}$ for the removal of black crusts were used (Figs. 4c,d)

In the areas where the biological patina was removed, layers of a brown or yellow colour were observed that were removed after a 3 times application of a paste of EDTA $12 \%$ for 2 hours. Layers of yellow ferrous oxides, formed due to the oxidation of the mineral iron present in the marble, were observed in some areas in the lower part of the statue after the cleaning. These layers can be removed with an application of compress of a solution of thioglycolic acid 5\%, neutralized with $\mathrm{NH}_{3}$ for 1-2 minutes.

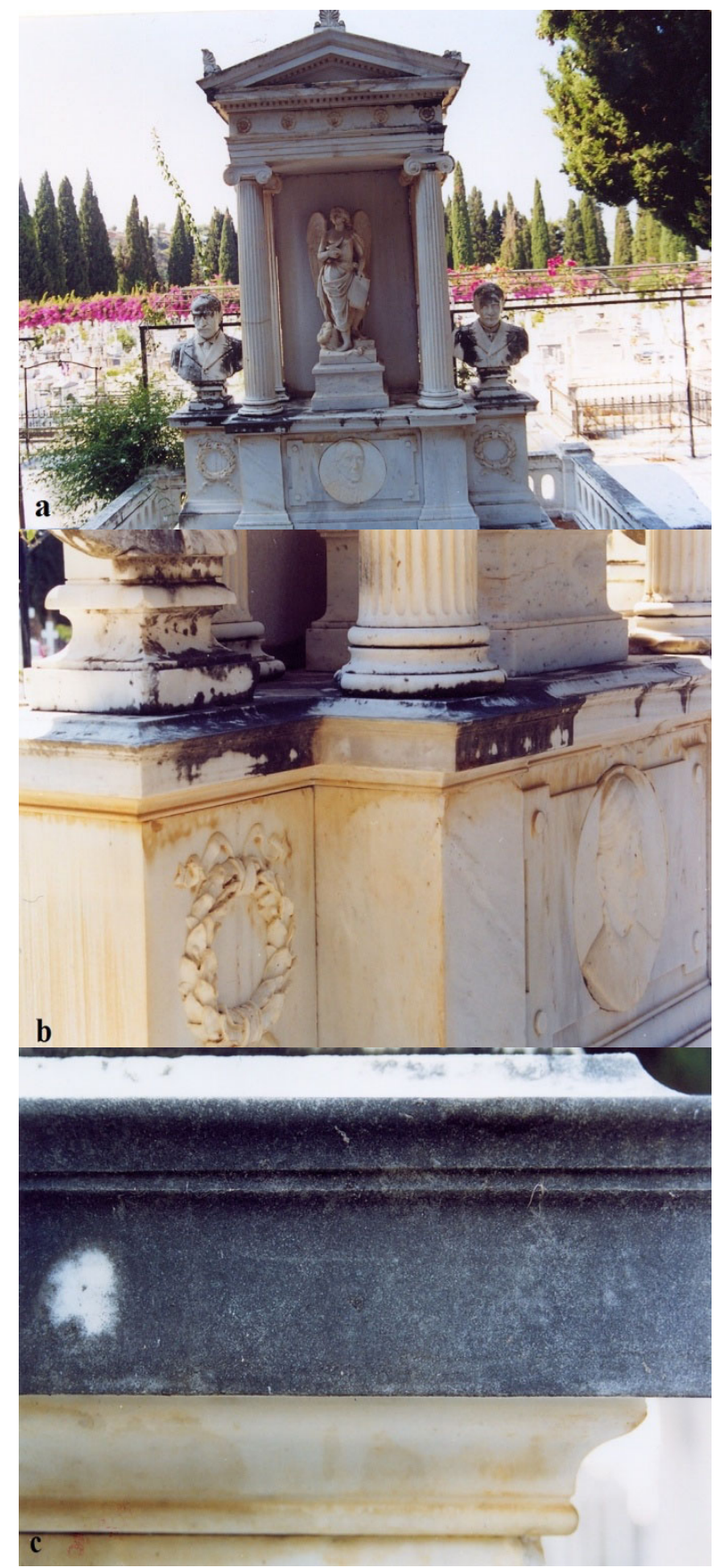

Figure 4 In situ application of cleaning methods on a marble monument (Kosmetatos statue); a: general view (initial situation), b: detail (initial situation), c: intermediate step, d: final situation.

\section{CONCLUSIONS}

1. The material used for the construction of the marble monuments was the same and is mainly composed of calcite (96-99\%), the remaining being quartz and clays. The results were similar for both bulk and surface samples of marble. Deterioration problems due to air pollution or acid attack were not observed.

2. Chlorides exhibited elevated concentrations, suggesting transport of marine aerosol in rain water and salt water intrusion from the sea in surface water Absence of significant amounts of nitrates or sulphates is observed in the rain and surface waters.

3. The main deterioration problem of the materials is biodeterioration, due to the growth of microorganisms, bacteria and plants, enhanced from the particular environmental conditions with thick layers of biological patina covering great parts of the surfaces of materials.

4. From the various mechanical and chemical cleaning methods tested in the laboratory, the best results were obtained with the use of a combination of hydrogen peroxide and microsandblast. The material of microsandblast was thin powder of small bullets (diameter 50-150 $\mu \mathrm{m}$ ) of $\mathrm{Al}_{2} \mathrm{O}_{3}$.

5. Satisfactory results from the in situ tests in the monuments were obtained when a method of combination of hydrogen peroxide solutions, EDTA, $\mathrm{NH}_{4} \mathrm{HCO}_{3}$ solution and organic solvent was applied in various steps on to the whole monument surface or part of it, according the kind and the thickness of the patina in the various parts of the monument.

\section{References}

Ahmadjian, V., Jacobs, J.B., (1983) "Algal-fungal relationships in lichens: Recognition, synthesis and development. In: Algal Symbiosis" Goff L.J. ed., Cambridge University Press, Cambridge. 
Ascaso, C., Wiertzchos, J., (1994) "Structural aspects of the lichen-rock interface using back-scattered electron imaging" Bot. Acta, 107, 251-256.

Camuffo, D., Del Monte, M., Sabbioni, C., Vittori, O., (1982)

"Wetting deterioration and visual features of stone surfaces in an urban area" Atmospheric Environment 16-9, 2253-2259.

Camuffo, D., Del Monte, M., Sabbioni, C., (1983) "Origin and growth mechanisms of the sulfated crusts on urban limestone" Water, Air and Soil Pollution 19, 351-359.

Del Monte, M., Sabbioni, C., Ventura, A., Zappia, G., (1984) "Crystal growth from carbonaceous particulates" The Science of the Total Environment 36, 247-254.

Keatings, K., Tassie, G.J., Flower, R.J., Hassan, F.A., Hamdan, M.A.R., Hughes, M., Arrowsmith, C., (2007) "An Examination of Groundwater Within the Hawara Pyramid, Egypt" Geoarchaeology: An International Journal, 22, 5, 533-554.

Kounadi-Papadatou b., The monuments of Drapano in Kefalonia, Athens, 1985.

Lan, T.T.N., Nishimura, R., Tsujino, Y., Satoh, Y., Thoa, N.T.P., Yokoi, M., Maeda, Y., (2005) "The effects of air pollution and climatic factors on atmospheric corrosion of marble under field exposure" Corrosion Science, 47, 10231038.

Markatou Th., The cemetery of Drapano in Argostoli, Kefaliniaka Chronika, V.6, (1994), pp. 510-549.

Moreno, F., Vilela, S.A.G, Antunes, A.S.G., Alves, C.A.S., (2006) "Capillary-rising salt pollution and granitic stone erosive decay in the parish church of Torre de Moncorvo (NE Portugal)-implications for conservation strategy" Journal of Cultural Heritage, 7, 56-66.

Price, C.A., (1996) "Stone conservation: an overview of current research" Getty Conservation Institute, Santa Monica, CA, xiii, 73 pp.

Rodriguez-Navarro, C., Sebastian, E., (1996) "Role of particulate matter from vehicle exhaust on porous stones (limestone) sulfation" The Science of the Total Environment 187, 79-91.

Sawidis, T., Chettri, M.K., Zachariadis, G., Stratis, I., Seaward, M.R.D., (1995) "Heavy metal bioaccumulation in lichens from Macedonia in Northern Greece" Toxic Environ. Chemistry, 50, 157-166.

Scagel, R.F., Badoni, R.J., Rouse, G.E., Schofield, W.B., Stein, J.R., Taylor, T.M.C., (1965) "An evolutionary survey of the plant kingdom" Wadsworth Publishing Company, Inc. Belmond, California.

Sharma, P.K., Khandelwal, M., Singh, T.N., (2007) "Variation on physico-mechanical properties of Kota stone under different watery environments" Building and Environment, 42, 4117-4123.

Simao, J., Ruiz-Agudob, E., Rodriguez-Navarro, C., (2006) "Effects of particulate matter from gasoline and diesel vehicle exhaust emissions on silicate stones sulfation" Atmospheric Environment, 40, 6905-6917.

Skoulikidis Th., Proposition for the cleaning of monuments of Acropolis, Report to the Committee of Conservation of Acropolis Monuments, Athens, 1994.

Skoulikidis, T., (2000) "Corrosion and conservation of the building materials of the monuments" University Editions of Creta

Tiano D., et al ; Intern. Colloquium: Methods of Evaluating products for the Conservation of Porous Building Materials in Monuments, ICCROM, Rome, (1995), pp.75-86.

Tzouganatos N., "The cemetery of Drapano", in "Studies of History and Folklore of Kefalonia", Athens, 1996.
Wilimzig M., and Bock E., Intern. Colloquium: Methods of Evaluating products for the Conservation of Porous Building Materials in Monuments, ICCROM, Rome, (1995), pp.87-92. Winkler, EM., (1997) "Stone in architecture: properties, durability" Springer-Verlag, Berlin; New York, xvi, 313 pp. Young, D., (2008) "Salt attack and rising damp, Technical Guide" Melbourne, Australia 